術後喉頭機能を保存した甲状腺癌喉頭浸潤例

\author{
山本 典生・庄司 和彦・児嶋 久剛 \\ 河田 恭孝・平野滋・篠原 尚吾*
}

\title{
Papillary Carcinoma of the Thyroid Gland with Severe Invasion of the Larynx ; A Case Report of Treatment with Preservation of Laryngeal Function
}

\author{
Norio Yamamoto, Kazuhiko Shoji, Hisayoshi Kojima, \\ Yasutaka Kawata and Shigeru Hirano \\ (Kyoto University) \\ Shogo Shinohara \\ (Kobe City General Hospital)
}

\begin{abstract}
Papillary carcinoma of the thyroid gland rarely invades the larynx because of its low malignancy and slow progression. When it does invade the larynx, however, laryngeal function should be preserved if possible. We describe a case of a 74-year-old man with advanced papillary carcinoma of the thyroid gland. The papillary carcinoma of the thyroid gland severely invaded his larynx, trachea and esophagus. Accordingly, we performed a total thyroidectomy, left neck dissection, partial laryngectomy, and partial excision of the trachea. However, laryngeal function was successfully preserved by reconstruction of the larynx and trachea using a composite auricular cartilage and skin graft.
\end{abstract}

Key words : thyroid carcinoma, laryngeal invasion, preservation of larynx, composite auricular cartilage graft

はじめに

甲状腺分化癌が喉頭に浸潤することは比較的少ないが， たとえ喉頭への浸潤がみられる例でも, 甲状腺癌の予後 が必ずしも不良ではないことを考えると，安易に喉頭全 摘出術を行わず，極力喉頭機能を保存することが望まれ る. 今回我々は, 喉頭, 気管, 食道に広く浸潤した甲状 腺乳頭癌の症例で, 喉頭気管部分切除と皮膚付さ自家耳 介軟骨移植による喉頭気管の再建によって喉頭機能を保 存しえたので報告する。
症例

患者: 74歳, 男性.

主訴：呼吸困難.

既往歴, 家族歴 : 特記事項なし.

現病歴 : 1981年頃より左頸部の母指頭大の腫瘤を自覚 し, 徐々に増大するも, 放置していた。1995年 2 月睡眠 中に突然, 呼吸困難発作出現したが自然に軽快した. 同 年11月同様の呼吸困難発作があったため，近医を受診し 甲状腺腫瘍を指摘された。同年12月，当科を受診し，高 度の気管狭窄に対し緊急気管切開を施行した。 
初診時所見：前頸部に $13 \times 5 \mathrm{~cm}$ の弾性硬，表面不整， 可動性不良の腫瘤があり, 左鎖骨上窩には径 $5 \mathrm{~mm}$ のリ ンパ節腫脤を認めた(図 1 )。声門下気管左側壁に腫瘤の 突出を認め, 喘鳴が聞かれ, 左声帯運動の制限があった が，腫瘍は声帯には及んでいなかった(図 2)。また，食 道内視鏡で頸部食道左側粘膜下に腫瘍の圧迫によって生 じたと思われる静脈溜を認めた(図３）。

血液検查所見：甲状腺機能は $\mathrm{fT}_{4} 1.83 \mathrm{ng} / \mathrm{dl}(0.98 \sim$

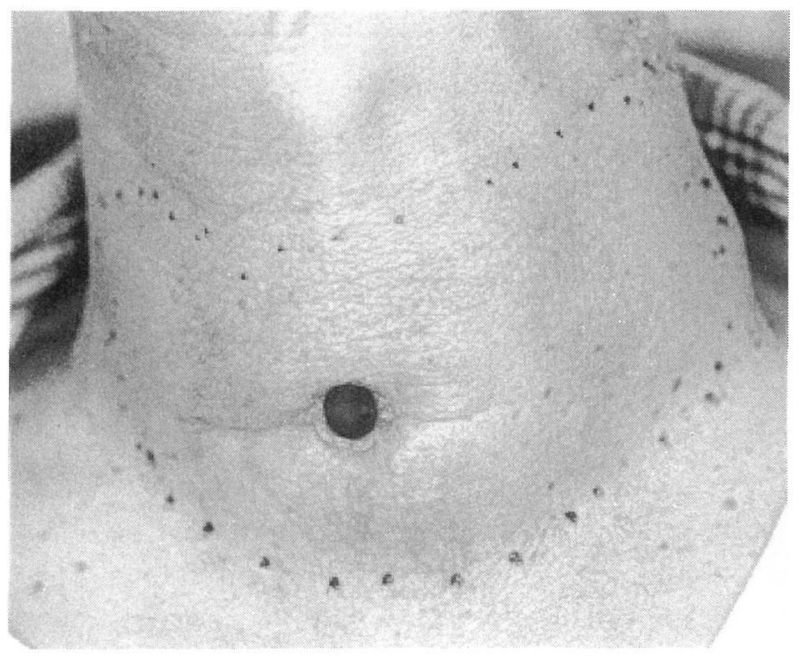

図 1 術前局所所見

前頸部に $13 \times 5 \mathrm{~cm}$ の弾性硬, 表面不整, 可動性不良の 腫瘤を認めた。
1.77), TSH $0.03 \mu \mathrm{U} / \mathrm{ml}$ 以下 $(0.3 \sim 3.9)$ と軽度九進し, サイログロブリンは $28400 \mathrm{ng} / \mathrm{ml}$ (45以下) と異常高值 であった，气の他の血液一般検查，生化学検查に異常は なかった。

CT 所見（図 4)：甲状腺全体占める石灰化を伴った $70 \times 30 \times 70 \mathrm{~mm}$ の造影効果のない腫瘍が存在し, 腫瘍 は甲状軟骨板左側, 輪状軟骨之気管の左半周にか㚈て進 展していた。腫瘍は気道に突出して気道を狭窄して掠り， 輪状軟骨の左半周を融解させていた。 リンパ節に腫脹が認められた。

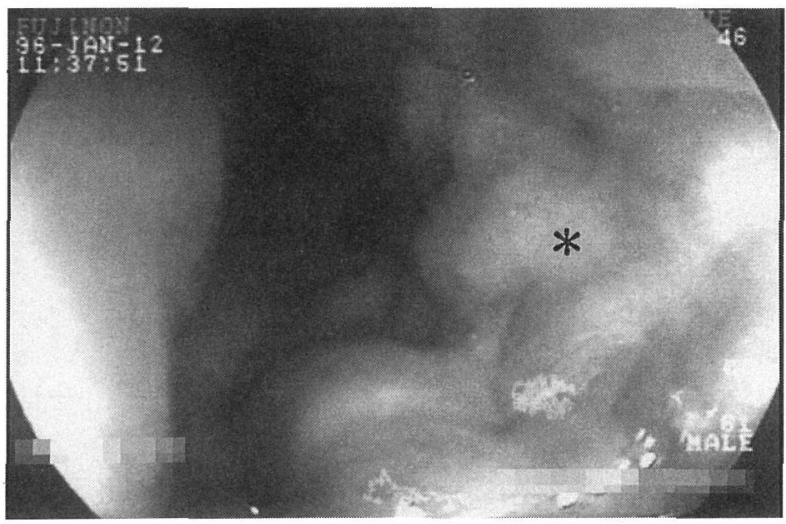

図 3 食道内視鏡所見 左側粘膜下に静脈瘤 $(*)$ を認める.

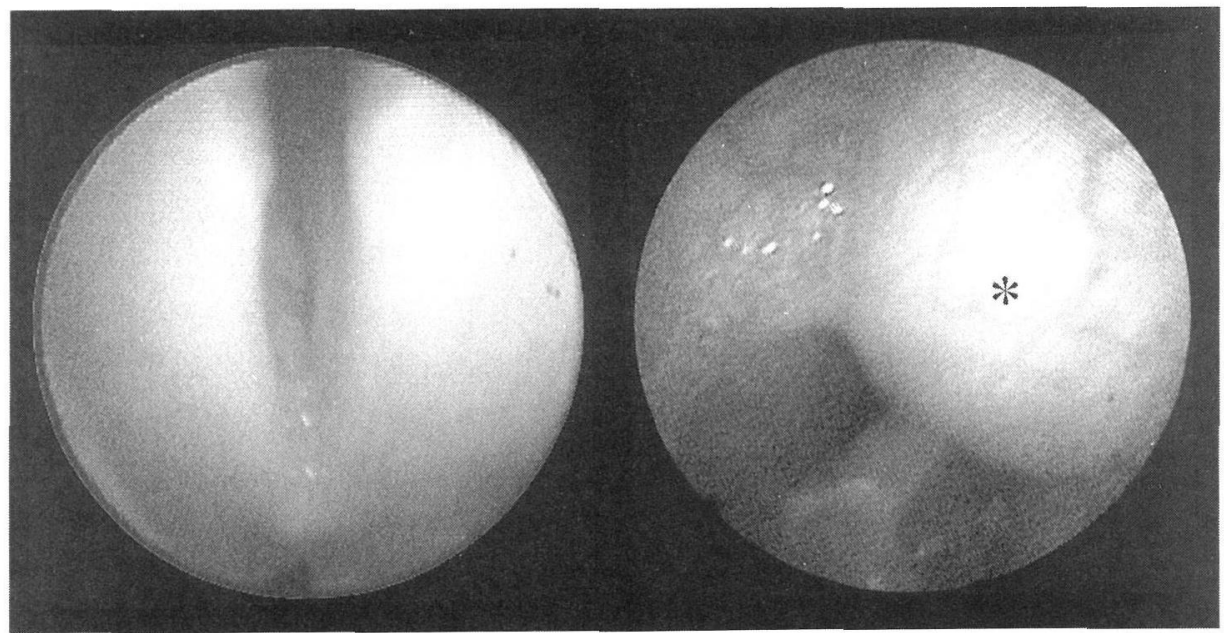

図 2 㬋頭所見

左：声帯に腫瘍は及んでいない。

右 : 声門下の気管左側壁に腫瘤の突出 $(*)$ を認める。 


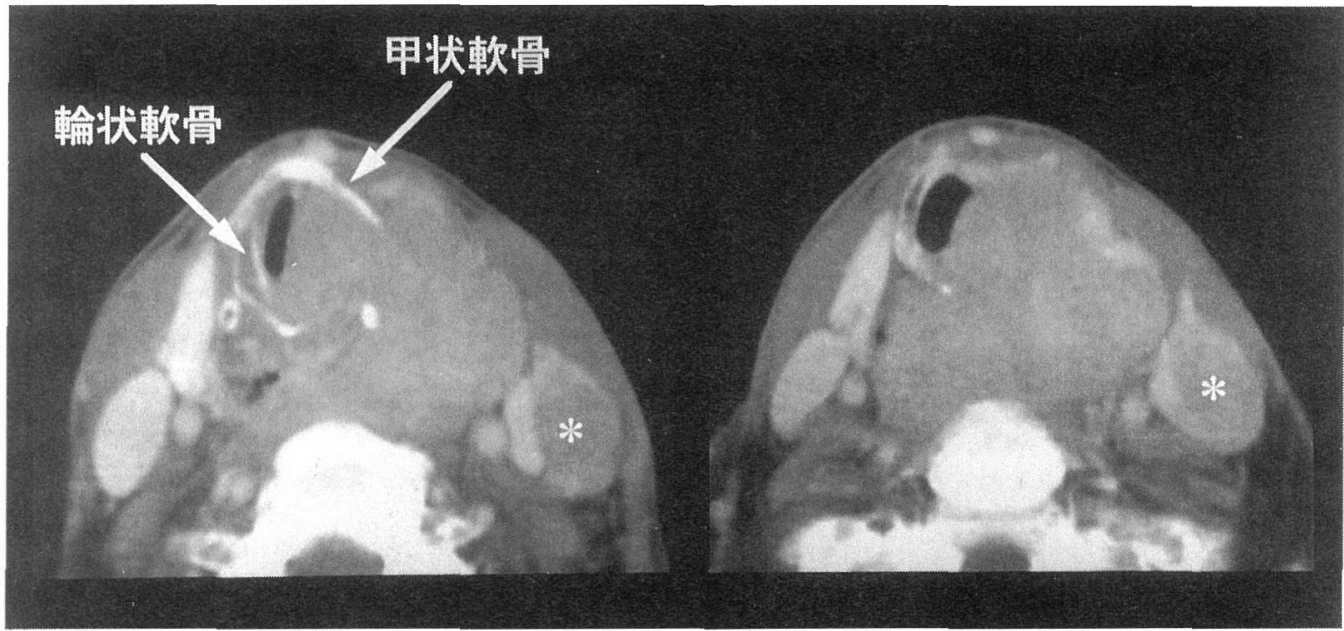

図 4 頸部 CT 所見

甲状軟骨, 輪状軟骨への腫瘍の浸潤が認められる.

* : 上内深頸りンパ節

穿刺吸引細胞診：甲状腺腫瘍の細胞診ではクラス $\mathrm{V}$ (乳頭癌)であった。

以上の所見より，喉頭への高度浸潤をきたした甲状腺 乳頭癌と診断し，声帯への浸潤を認めなかったため，喉 頭を保存する方針で手術を施行した。

手術：甲状腺腫瘍は甲状腺から, 甲状軟骨板左下 $1 / 3$, 左輪状披裂関節を含婨状軟骨左半側，気管左半周へ浸 潤していた。声門下内腔にも進展が認められたが，粘膜 面への浸潤はなかった。また，腯瘍は食道筋層へも浸潤 していた。左頸部にはリンパ節転移を多数認めた。この

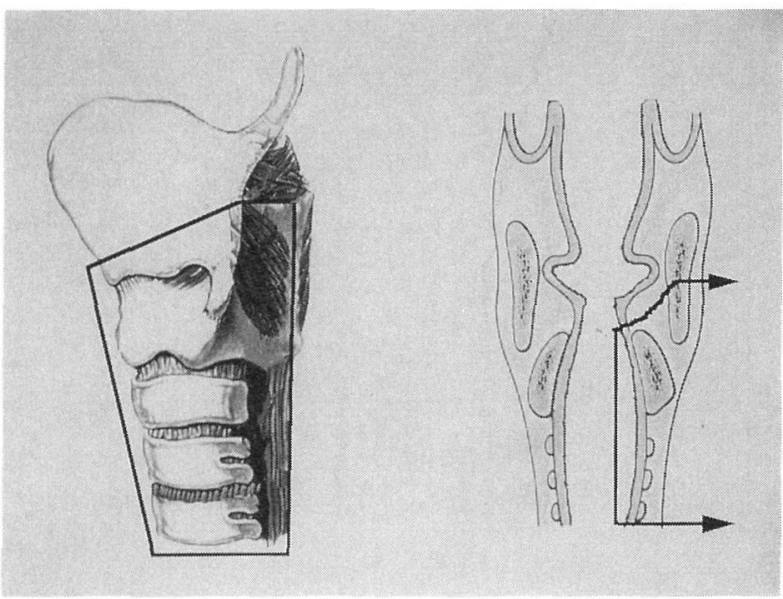

図 5 喉頭・気管の切除範用
ため, 甲状腺全摘出術, 左頸部郭清とともに, 甲状軟骨 板の左下 $1 / 3$ から輪状軟骨左半周, 気管第 3 気管輪まで の左半周, 左反回神経, 和よび浸潤がみられた食道筋層 合併切除した。喉頭・気管の切除範团を図 5 に示す。 声門上部, 両側声帯, 両側披裂軟骨, 食道粘膜は温存し た. $4 \times 2 \mathrm{~cm}$ の喉頭気管皮膚瘦を作成して手術を終了し た.図 6 に術後の頸部所見を示す. 術後の永久病理渗断 は, 乳頭癌であった。

術後 2 週目に，右耳介より $3 \times 1.5 \mathrm{~cm}$ の皮膚付き耳 介軟骨（図７）を採取し，喉頭気管皮膚瘦の右外側に作成

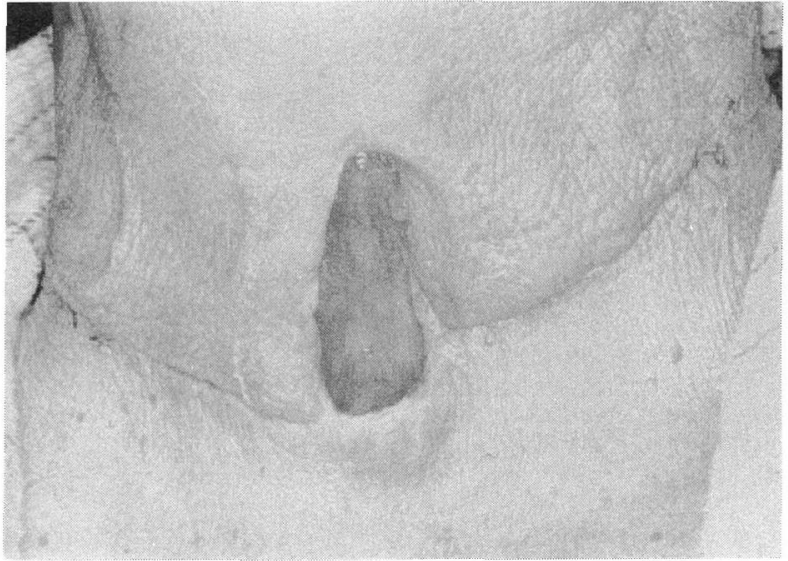

図 6 術後頸部所見 

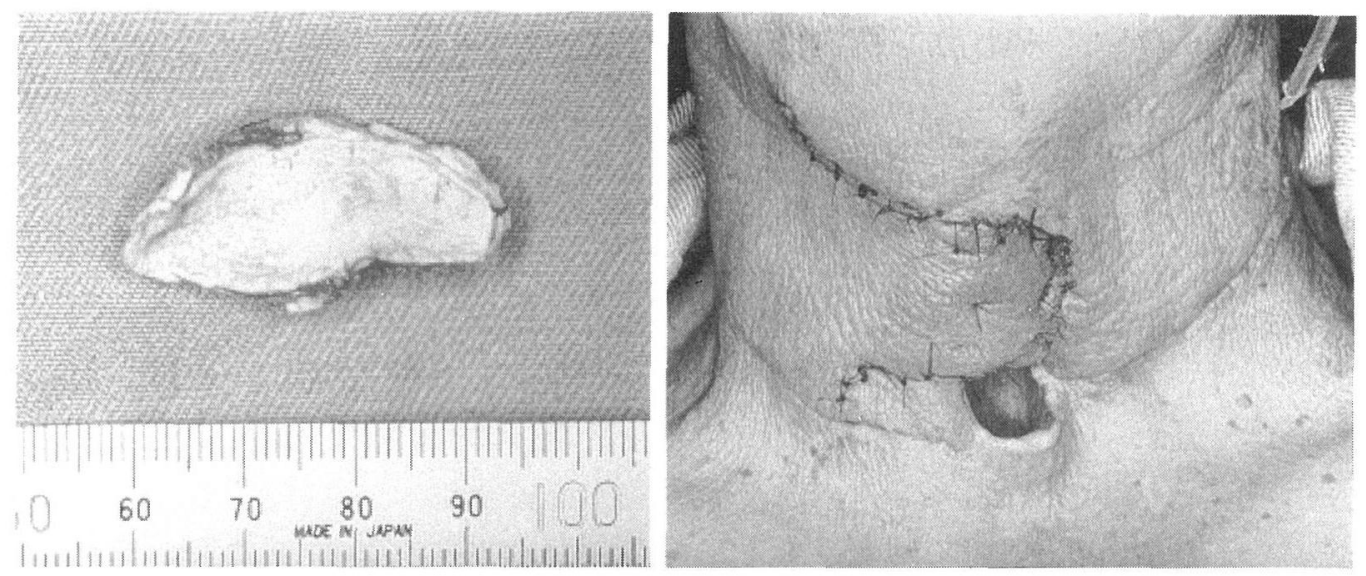

図 7 左：皮膚付き耳介軟骨

右：喉頭形成後局所所見

した皮膚ポケットに，皮膚面が背側を向くように軟骨を 埋め込久, 皮弁への血流在確保するために 2 週間留置し た。矢の後, 埋め込んだ皮膚付き軟骨执よび頸部皮膚を 一塊の進展皮弁として持ち上げて左側に進展させ，ナイ ロン系にて皮升の右端，上端，左端のそれぞれを喉頭気 管瘦の右端軟骨部，瘦の上端，瘻の左端皮膚之縫合した (図 7 )。これとより, 喉頭気管瘦の喉頭レベルの前壁と 左側壁は再建され, 瘦の上下径も $2.0 \mathrm{~cm}$ と縮小したが,
第 3 気管輪までの左側壁がなく, 瘦の閉鎖が困難であっ た。このため， 1 カ月後に気管孔の左側の皮膚の上下 2 力所傜長さ約 $20 \mathrm{~mm}$ の平行な切開学入れ，双茎皮弁を 作製し，左耳介より採取した自家左耳介軟骨をはさんで 持ら上げて気管左側壁を作成した。

術後経過: 術後, 皮膚軟骨複合皮弁の生着は良好であ った。喉頭形成術後 1 力月上り経口摂取を開始したが, 誤燕は認めなかった，患者の不安感が強いため気管切開
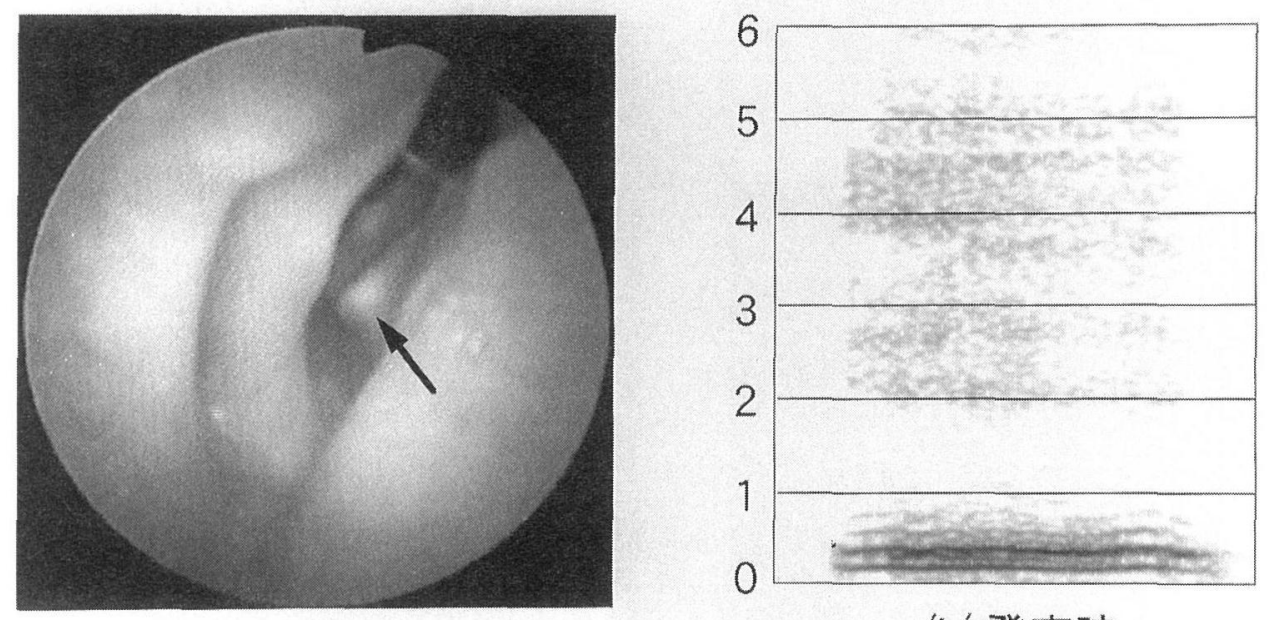

/ / 発声時

図 8 左: 術後喉頭所見 左声帯突起( 右：術後サウンドスペクトログラム 
孔は未だ閉鎖していないが，レティナ®カニューレに常 にシリコン栓をすることにより，良好な呼吸と発声とが 得られている. 図 8 に術後喉頭所見と, / i / 発声時のサ ウンドスペクトログラムを示す. 左声帯突起は前方に偏 位し, 左声帯は麻痺しているものの, 右声帯の可動性は 良好である. 発声時, 声門間陌があり気息性嗄声を呈し て扣り，スペクトログラムでは，高周波ノイズを認める が, 最大発声持続時間19秒と日常生活上, 十分な音声が 得られている.

\section{考察}

甲状腺乳頭癌症例で腫瘍が喉頭に浸潤している例は, 過去 7 年間での当科甲状腺乳頭癌手術症例 301 例のらち 8 例 (2.7\%)であった。これは McConahey ら)による 報告の $2.2 \%$ と注等しく，その頻度は低いと考兄られ る.このため, 喉頭全摘出の適応，喉頭を部分切除した 際の再建方法などについては様々な意見がみられる22 4).

桜井ら ${ }^{2)}$ は輪状軟骨より上方へ腫瘍が浸潤している場 合は喉頭全摘の適応であるとし，海老原3) は声帯に浸潤 が及ぶ場合には誤燕防止などの意味も含め, 喉頭全摘出 の適応であるが，輪状軟骨にとどまる場合は部分切除の 上，永久気管瘦を置くとしている，McCaffrey ら れば，甲状腺分化癌の気道食道浸潤例では，根治的な切 除と気道食道機能を温存した術式との間では生存率の差 はないとしている。また，喉頭浸潤の場合は一側の浸潤 例が多いので喉頭半切除または甲状軟骨板の切除に留め, 軟骨移植により気道や発声の機能を温存しらるが, 輪状 軟骨の $1 / 3$ 周以上が切除された場合は, 喉頭全摘出の適 応であると述べている。

本症例を除く当科での甲状腺乳頭癌の喉頭浸潤例 7 例 のらち，声帯への浸潤と皮膚への浸潤のあった 1 例では 喉頭全摘出術を施行した。 しかし, その他 6 例では, 腫 瘍の浸潤が甲状軟骨, 輪状軟骨または甲状輪状筋のみへ の浸潤であったため，軟骨もしくは筋肉のみの削除だけ で腫瘍を切除しえた。本症例では, 喉頭への高度の浸潤 があったが, 術前のCT 㧊よび喉頭内視鏡所見から, 腫 瘍の浸潤が声帯に及んでいないことが確認されたので， 喉頭全摘出術は行わず，声帯を温存することができた． 甲状腺分化癌喉頭浸潤例の場合, その進展の速度と術後 の患者の quality of life を考慮すれば, 本症例のように, 声帯に直接浸潤のない限り，喉頭の機能を残す方針で臨 むことが適切であろらと考兄らる。 その際に，腫瘍の
進展範囲を評価するには，桜井ら2)が述べているように CT の所見が有用であった。

喉頭の部分切除が広範囲に及べば，何らかの材料によ る再建が機能の温存のためには必須となるが，本症例で は，皮膚付き自家耳介軟骨を用いて喉頭の再建を行った， 人工材料は異物反応，感染などの問題があり，自家軟骨 の使用はこのよらな合併症を避けるために有効な手段で ある. 自家軟骨としては, 耳介軟骨5), 鼻中隔軟骨6), 肋軟骨5)などが用いられるが, 今回我々は, 遊離移植片 のサイズが大きかったので, 術後の壊死防止のために, 皮膚付き自家耳介軟骨を予喉頭気管皮膚瘻外側の皮下 に埋込んで移植片への血流を確保した上で喉頭の形成を 行う方法をとった。

先にも述べたように, 甲状腺癌が喉頭気管に高度に浸 潤していても, 乳頭癌そのものは予後は必ずしも不良で はない, このため, 本症例のように声帯を温存して腫瘍 を摘出し，複合皮弁を用いて血流を十分に確保するとい ら再建方法を選択することで, 喉頭機能を温存できる場 合がある，商応を厳格にしなければならないが，症例に よっては喉頭の温存を念頭においた治療を考慮すべきで あろら。

\section{まとめ}

1.甲状腺乳頭癌の喉頭浸潤例で皮膚付き自家耳介軟 骨を用いて喉頭機能を温存しえた 1 例を報告した.

2. 甲状腺乳頭癌においては, 喉頭に浸潤が認められ ても, 術前のCT, 喉頭内視鏡などを用い, 声帯への浸 潤がないと判断されれば, 可能なかぎり声帯を温存する 術式を選択すべきである.

3. 喉頭の切除範囲が広範囲に及んだ場合, 喉頭・気 管形成が必要であるが, その際, 皮膚付き自家耳介軟骨 は有用な再建材料であった。

稿を終えるにあたり, 御校閱を賜りました京都大学大学院医 学研究科 感覚運動系病態学講座 聴覚・言語病態学領域, 本庄 珤教授に深謝致します。

本論文の要旨は, 第 58 回耳鼻咽喉科臨床学会 (平成 8 年 6 月, 名古屋)に㧊いてロ演した。

\section{参考文献}

1) McConahey WM, Hay ID, Woolner LB, et al : Papillary thyroid cancer treated at the Mayo Clinic, 1946 through 1970 ; initial manifestations, pathologic findings, therapy 
and outcome. Mayo Clin Proc 61 : 978 996, 1986.

2 ) 桜井一生, 岩田重信, 高須昭彦, 他 : 喉頭 - 気管に浸潤し た甲状腺癌症例の検討. 日気食会報 $38: 59 \sim 62,1987$.

3 ）海老原敏：周囲組織に浸潤した甲状腺癌. 外科 $55: 1339$ $\sim 1342,1993$.

4) McCaffrey TV and Lipton RJ : Thyroid carcinoma invading the upper aerodigestive system. Laryngoscope $100: 824 \sim 830,1990$.

5 ) Lusk RP, Kang DR and Muntz HR : Auricular cartilage grafts in laryngeal reconstruction. Ann Otol Rhinol
Laryngol $102: 247 \sim 254,1993$.

6) Duncavage JA, Ossoff RH and Toohill RJ : Laryngotracheal reconstruction with composite nasal septal cartilage grafts. Ann Otol Rhinol Laryngol $98: 581 \sim 585$, 1989.

$\left(\begin{array}{l}\text { 原稿受付 : 平成 } 8 \text { 年 } 8 \text { 月 } 22 \text { 日 } \\ \text { 原稿採択 : 平成 } 8 \text { 年 } 11 \text { 月 } 6 \text { 日 } \\ \text { 別刷請求先 : 山本典生 } \\ \text { † } 632 \text { 天理市三島町 } 200 \\ \text { 天理よろつ相談所病院耳鼻咽喉科 }\end{array}\right)$

